\title{
PENGARUH PROFITABILITAS TERHADAP HARGA SAHAM PERUSAHAAN MANUFAKTUR SEKTOR MAKANAN DAN MINUMAN DI BEI TAHUN 2014 - 2015
}

\author{
Anita Suwandani, Suhendro, Anita Wijayanti \\ anita.suwandani@yahoo.com
}

FE UNIBA Surakarta

\begin{abstract}
ABSTRAK
Tujuan penelitian ini adalah 1) untuk mengetahui profitabilitas dari rasio ROA berpengaruh positif dan signifikan terhadap harga saham perusahaan manufaktur yang terdaftar di BEI tahun 2015, 2) untuk mengetahui profitabilitas dari rasio ROE berpengaruh positif dan signifikan terhadap harga saham perusahaan manufaktur yang terdaftar di BEI tahun 2015, 3) untuk mengetahui profitabilitas dari rasio EPS berpengaruh positif dan signifikan terhadap harga saham perusahaan manufaktur yang terdaftar di BEI tahun 2015, 4) untuk mengetahui profitabilitas dari rasio NPMS berpengaruh positif dan signifikan terhadap harga saham perusahaan manufaktur yang terdaftar di BEI tahun 2015,5) untuk mengetahui profitabilitas dari rasio ROA, ROE, EPS dan NPM berpengaruh secara bersama-sama dan signifikan terhadap harga saham perusahaan manufaktur yang terdaftar di BEI tahun 2015.

Metode penelitian ini adalah kuantitatif dengan analisis pengolahan data dari Indonesian Capital Market Directory tahun 2015. Pengumpulan data sekunder dengan dokumentasi. Teknik analisis data yang digunakan uji validitas, uji reliabilitas, uji asumsi klasik, analisis regresi linier berganda, uji t, uji F, koefisien determinasi $\left(\mathrm{R}^{2}\right)$.

Hasil analisis regresi variabel profitabilitas dari rasio EPS pengaruhnya positif terhadap harga saham dan pengaruh variabel ROA, ROE dan NPM berpengaruh negatif terhadap harga saham. Pengaruh signifikan variabel ROE terhadap harga saham. Variabel ROA, EPS dan NPM berpengaruh tidak signifikan terhadap harga saham. Namun secara bersama-sama semua variabel profitabilitas dari rasio ROA, ROE, EPS dan NPM berpengaruh tidak signifikan. Besarnya harga saham perusahaan manufaktur yang terdaftar di BEI tahun 2015 dapat dijelaskan oleh variabel profitabilitas dari rasio ROA, ROE, EPS dan NPM sebesar 5,4\%.
\end{abstract}

Kata kunci: Profitabilitas (ROA, ROE, EPS dan NPM) dan harga saham 


\section{PENDAHULUAN}

Profitabilitas merupakan indikator yang paling penting untuk mengukur kinerja suatu perusahaan yang memfokuskan kemampuan perusahaan untuk memperoleh earning dalam kegiatan operasi perusahaan dengan memanfaatkan aktiva yang dimilikinya. Sehingga dalam penelitian ini profitabilitas digunakan sebagai ukuran kinerja perusahaan. utamanya operasional perusahaan adalah mencapai tingkat profitabilitas yang maksimal. Profitabilitas penting bagi perusahaan karena profitabilitas digunakan untuk mengukur efektivitas perusahaan di dalam menghasilkan keuntungan dengan memanfaatkan aktiva yang dimilikinya. Profitabilitas merupakan kemampuan untuk menghasilkan/memperoleh laba secara efektif dan efisien. Profitabilitas yang digunakan adalah ROA, ROE, EPS dan NPM karena dapat memperhitungkan kemampuan manajemen perusahaan dalam mengelola aktiva yang dimilikinya untuk menghasilkan income. Semakin besar profitabilitas perusahaan, semakin besar pula tingkat keuntungan yang dicapai perusahaan tersebut dan semakin baik pula posisi perusahaan tersebut dari segi penggunaan asset (Lukman Dendawijaya, 2000). Hal itu menunjukkan bahwa profitabilitas yang tinggi dari perusahaan maka akan dapat meningkatkan kemampuan perusahaan sehingga akan membut perusahaan juga meningkat harga sahamnya.

Bagi investor informasi tentang rasio profitabilitas menjadi kebutuhan yang sangat mendasar dalam kebutuhan pengambilan keputusan. Perkembangan harga saham tidak terlepas dari perkembangan kinerja perusahaan yang ditunjukkan dengan profitabilitas perusahaan. Secara toritis jika kinerja perusahaan mengalami peningkatan maka harga saham akan merefleksikannya dengan peningkatan harga saham demikian sebaliknya (Ang dalam Sri
Artatik, 2007: 187). Bisa dikatakan bahwa semakin tinggi profitabilitas perusahaan maka akan membuat harga saham juga terpengaruh. Dengan meningkatnya profitabilitas maka harga saham cenderung naik, sedangkan ketika laba menurun maka harga saham ikut juga turun.

Penelitian ini bertujuan untuk menguji pengaruh rasio profitabilitas terhadap harga saham pada perusahaan manufaktur yang terdaftar di BEI. Variabel-variabel rasio profitabilitas yang diteliti adalah empat rasio yaitu ROA, ROE, EPS dan NPM. Astuti (2004: 37) menyatakan bahwa Return on Asset (ROA) digunakan untuk mengukur pengembalian atas total aktiva setelah bunya dan pajak. Hasil pengembalian total aktiva atau total investasi menunjukkan kinerja manajemen dalam menggunakan aktiva perusahaan untuk menghasilkan laba (profitabilitas) Sedangkan Return On Equity (ROE) menggambarkan sejauhmana kemampuan perusahaan menghasilkan laba yang bias diperoleh pemegang saham.

Tambunan (2007: 146) menyatakan bahwa para analisis sekuritas dan pemegang saham umumnya sangat memperhatikan rasio Retunr on Asset (ROA). ROA penting bagi perusahaan karena ROA digunakan untuk mengukur efektivitas perusahaan di dalam menghasilkan keuntungan dengan memanfaatkan aktiva yang dimilikinya. ROA merupakan rasio antara laba sesudah pajak terhadap total asset. Semakin besar ROA menunjukkan kinerja perusahaan semakin baik, karena tingkat kembalian (return) semakin besar.

Rasio EPS memberikan gambaran mengenai kemampuan perusahaan dalam menghasilkan keuntungan bersih dalam setiap lembar saham. EPS mempunyai pengaruh yang kuat terhadap harga saham dan ketika EPS meningkat maka harga saham juga meningkat, demikian pula sebaliknya. 
Rasio NPM ini dapat digunakan untuk mengukur seberapa besar laba bersih yang dapat diperoleh dari setiap rupiah penjualan perusahaan. Disamping itu rasio ini juga bermanfaat untuk mengukur tingkat efisiensi total pengeluaran biaya-biayanya dalam perusahaan, semakin efisien suatu perusahaan dalam pengeluaran biaya-biayanya, maka semakin besar tingkat keuntungan yang akan diperoleh perusahaan tersebut.

Dalam penelitian ini peneliti memilih perusahaan manufaktur sebagai sampel yang diteliti karena perusahaan manufaktur merupakan perusahaan yang memiliki cakupan yang luas dan juga stabil dalam menghadapi perubahan ekonomi. Berdasarkan hal tersebut maka maka peneliti tertarik untuk melakukan penelitian untuk mengetahui apakah ada pengaruh profitabilitas terhadap harga saham pada perusahaan manufaktur di BEI tahun 2015.

\section{TINJAUAN PUSTAKA}

\section{Profitabilitas}

Profit dalam kegiatan operasional perusahaan merupakan elemen penting untuk menjamin kelangsungan hidup perusahaan pada masa yang akan datang. Keberhasilan perusahaan dapat dilihat dari kemampuan perusahaan menciptakan laba yang berasal dari pembiayaan yang dilakukan, kemampuan perusahaan untuk dapat bersaing di pasar dan kemampuan perusahaan untuk dapat melakukan ekspansi usaha.

Profitabilitas atau disebut dengan rentabilitas adalah kemampuan suatu perusahaan untuk menghasilkan laba selama periode tertentu. Rentabilitas perusahaan menunjukkan perbandingan antara laba dengan aktiva atau modal yang menghasilkan laba tersebut. Salah satu cara untuk melihat keberhasilan suatu perusahaan adalah melalui profitabilitas perusahaan tersebut. Profitabilitas menunjukkan keberhasilan perusahaan dalam menghasilkan keuntungan atau laba. Semakin tinggi profitabilitas suatu perusahaan maka semakin tinggi pula kemampuan perusahaan tersebut dalam menghasilkan laba. Profitabilitas juga merupakan suatu indikator kinerja yang dilakukan manajemen dalam mengelola kekayaan perusahaan yang ditunjukkan dengan laba yang dihasilkan.

Profitabilitas adalah rasio yang menunjukkan kemampuan perusahaan untuk memperoleh laba. Rasio yang digunakan antara lain adalah :

a. Return On Equity (ROE)

Menurut Riyanto (2001) formula yang digunakan untuk menghitung Rate Of Return On Equity / ROE (Pengembalian atas ekuitas biasa) adalah:

$$
=\frac{\text { Laba bersih setelah pajak }}{\text { Ekuitas }}
$$

b. Return On Asset (ROA)

Profitabilitas diukur dengan ROA yang mengukur kemampuan manajemen bank dalam memperoleh keuntungan (laba) secara keseluruhan (Dendawijaya, 2000). Sedangkan menurut Malayu Hasibuan (2002) profitabilitas bank adalah kemampuan suatu bank untuk memperoleh laba yang dinyatakan dalam persentase. Profitabilitas pada dasarnya adalah laba (rupiah) yang dinyatakan dalam persentase profit. 


$$
R O A=\frac{\text { Laba Sebelum Pajak }}{\text { Total Modal (Aktiva) }} \times 100 \%
$$

\section{c. Earning Pershare (EPS)}

EPS merupakan besarnya laba bersih perusahaan yang siap dibagikan pada pemegang saham. Menurut Husnan (2005) formula yang digunakan untuk menghitung EPS adalah:

$$
=\frac{\text { Laba }}{\text { JumlahLembarsaham }}
$$

\section{d. Net Profit Margin Ratio (NPM)}

Menurut Riyanto (2001) formula yang digunakan untuk menghitung Net Profit Margin Ratio (Rasio margin laba bersih) adalah:

$$
=\frac{\text { Laba bersih }}{\text { Penjualan }}
$$

\section{Harga Saham}

Saham adalah tanda bukti pengambilan bagian atau peserta dalam suatu Perseroan Terbatas (PT) (Riyanto, 2006: 240). Saham menurut Robert Ang (dalam Sri Artatik, 2007: 22) adalah surat berharga sebagai tanda kepemilikan atas perusahaan penerbitnya. Dari pengertian saham tersebut maka dapat disimpulkan bahwa saham adalah surat bukti kepemilikan seseorang terhadap suatu perusahaan.

Jenis-jenis saham menurut Jogiyanto (2003: 67) dapat dibagi menjadfi 3 yaitu :
a. Saham Preferen
b. Saham Biasa
c. Saham Teasuri

Faktor-faktor yang mempengaruhi pergerakan harga saham menurut Arifin (dalam Sri Artatik, 2007: 115-116) adalah sebagai berikut :

a. Kondisi fundamental emiten

b. Hukum permintaan dan penawaran

c. Tingkat suku bunga

d. Valuta asing

e. Dana asing dibursa

f. Indeks harga saham

g. News and rumors

Begitu banyaknya faktor-faktor yang mempengaruhi harga saham, dalam penelitian ini akan difokuskan pada faktor fundamental emiten yaitu terkait dengan kinerja keuangan perusahaan yaitu dari profitabilitas perusahaan sebagai pertimbangan utama dalam menentukan harga saham.

\section{METODE PENELITIAN}

1. Jenis Penelitian

Jenis penelitian ini adalah penelitian kuantitatif dengan metode regresional. Penelitian dilakukan pada perusahaan manufaktur sector makanan dan minuman yang terdaftar di BEI tahun 2014-2015. Analisis pengolahan data diperoleh dari Indonesian Capital Market Directory.

\section{Sumber Data}

Data penelitian ini adalah data sekunder. Data sekunder adalah data yang diperoleh secara tidak langsung oleh peneliti. Data sekunder ini misalnya dicari melalui data dokumentasi yang telah dibukukan oleh perusahaan yang diteliti, buku-buku, majalah, keterangan-keterangan atau 
publikasi lainnya(Lincoln Arsyad, 2002: 57).

3. Populasi dan sampel

Populasi merupakan keseluruhan yang diteliti, kejadian, atau peristiwa yang menjadi perhatian para peneliti untuk diteliti (Sekaran, 2000). Populasi yang digunakan sebagai sample frame penelitian ini adalah seluruh perusahaan Manufaktur yang telah go public di Indonesia yang terdaftar di Bursa Efek Indonesia selama 2015 sebanyak 126 perusahaan manufaktur.

Sampel merupakan bagian dari populasi yang terdiri dari elemen-elemen yang diharapkan memiliki karakteristik yang mewakili populasinya. Sampel perusahaan yang digunakan dalam penelitian dipilih secara purposive sampling dimana sampel yang dipilih sesuai dengan kriteria-kriteria yang sudah ditentukan yaitu kriterianya perusahaan manufaktur yang bergerak dalam bidang makanan dan minuman ada sebanyak 29 perusahaan.

4. Instrumen Penelitian

Data yang digunakan dalam penelitian ini dikumpulkan dengan metode dokumentasi yaitu dengan menggunakan referensi dari Indonesian Capital Market Directory terhadap Laporan Keuangan perusahaan Manufaktur yang terdaftar di Bursa Efek Indonesia selama periode 2014-2015.

5. Teknik Analisis Data

a. Uji Asumsi Klasik

1) Uji normalitas
2) Uji Autokorelasi

c. Uji Hipotesa

1) Analisa regresi linier berganda

Analisa ini digunakan untuk mengetahui pengaruh antara variabel bebas yaitu Profitabiltas dari rasio ROA $\left(\mathrm{X}_{1}\right), \operatorname{ROE}\left(\mathrm{X}_{2}\right)$, EPS $\left(\mathrm{X}_{3}\right)$ dan NPM $\left(X_{4}\right)$ terhadap variabel terikat harga saham (Y), dengan rumus :

$\mathrm{Y}=\mathrm{a}+\mathrm{b}_{1} \mathrm{X}_{1}+\mathrm{b}_{2} \mathrm{X}_{2}+\mathrm{b}_{3} \mathrm{X}_{3}+\mathrm{b}_{3} \mathrm{X}_{4}+\mathrm{e}$ (Djarwanto PS, 2000: 309)

Dimana :

$\mathrm{Y} \quad=$ Harga saham

a = Nilai konstan

$\mathrm{b}_{1} \mathrm{~b}_{2}=$ Koefisien regresi $\mathrm{X}$

$\mathrm{X}_{1}=\mathrm{ROA}$ (Return On Asset)

$\mathrm{X}_{2} \quad=\mathrm{ROE}$ (Return On Equity)

$\mathrm{X}_{3}=$ EPS (Earning Pershare)

$\mathrm{X}_{2} \quad=$ NPM (Net Profit margin

$\mathrm{e} \quad=$ Error

2) Uji F

Uji $F$ ini untuk menguji tingkat signifikansi pengaruh bersama-sama variabel bebas Profitabilitas rasio ROA $\left(\mathrm{X}_{1}\right), R O E\left(\mathrm{X}_{2}\right)$, EPS $\left(\mathrm{X}_{3}\right)$ dan NPM $\left(X_{4}\right)$ terhadap variabel terikat harga saham $(\mathrm{Y})$.

3) Uji t

Uji ini untuk menguji tingkat signifikansi pengaruh masing-masing atau secara parsial variabel bebas Profitabilitas rasio ROA $\left(\mathrm{X}_{1}\right), R O E$ $\left(\mathrm{X}_{2}\right)$, EPS $\left(\mathrm{X}_{3}\right)$ dan NPM $\left(\mathrm{X}_{4}\right)$ terhadap variabel terikat harga saham (Y).

4) Koefisien Determinasi $\left(R^{2}\right)$

Koefisien determinasi $\left(\mathrm{R}^{2}\right)$ adalah untuk mengetahui derajat pengaruh dalam bentuk persentase variabel 
bebas (provitabilitas rasio ROA $\left(\mathrm{X}_{1}\right)$, $R O E\left(\mathrm{X}_{2}\right)$, EPS $\left(\mathrm{X}_{3}\right)$ dan NPM $\left(\mathrm{X}_{4}\right)$ terhadap variabel terikat harga saham (Y)

\section{HASIL DAN PEMBAHASAN}

Tujuan dari penelitian ini untuk mengetahui profitabilitas dari rasio ROA berpengaruh positif dan signifikan terhadap harga saham perusahaan manufaktur yang terdaftar di BEI tahun 2015, untuk mengetahui profitabilitas dari rasio ROE berpengaruh positif dan signifikan terhadap harga saham perusahaan manufaktur yang terdaftar di BEI tahun 2015, untuk mengetahui profitabilitas dari rasio EPS berpengaruh positif dan signifikan terhadap harga saham perusahaan manufaktur yang terdaftar di BEI tahun 2015, untuk mengetahui profitabilitas dari rasio NPM berpengaruh positif dan signifikan terhadap harga saham perusahaan manufaktur yang terdaftar di BEI tahun 2015 dan untuk mengetahui profitabilitas dari rasio ROA, ROE, EPS dan NPM berpengaruh secara bersama-sama dan signifikan terhadap harga saham perusahaan manufaktur yang terdaftar di BEI tahun 2015. Sampelnya adalah perusahaan manufaktur sektor makanan dan minuman. Hasil analisis regresi diketahui variabel profitabilitas dari rasio ROA, ROE dan EPS pengaruhnya negatif terhadap harga saham dan pengaruh variabel NPM berpengaruh positif terhadap harga saham. Pengaruh signifikan variabel NPM terhadap harga saham. Variabel ROA, ROE, dan EPS berpengaruh tidak signifikan terhadap harga saham. Dan secara bersama- sama semua variabel profitabilitas dari rasio ROA, ROE, EPS dan NPM berpengaruh tidak signifikan juag terhadap harga saham. Besarnya harga saham perusahaan manufaktur yang terdaftar di BEI tahun 2015 dapat dijelaskan oleh variabel profitabilitas dari rasio ROA, ROE, EPS dan NPM sebesar 5,4\%.

\section{KESIMPULAN}

Perusahaan manufaktur sektor makanan dan minuman yang terdaftar di BEI tahun 20142015 tingkat profitabilitasnya hampir sebagian besar rasionya tidak mempengaruhi harga saham hanya satu rasio yang berpengaruh terhadap harga saham yaitu rasio EPS.

\section{DAFTAR PUSTAKA}

Ali, Arifin. 2004. Manajemen keuangan (Teori dan Aplikasi).Yogyakarta: BPFE.

Dahlan, Siamat. 2005. Manajemen Lembaga Keuangan "Kebijakan Moneterdan Perbankan".Jakarta: Fakultas Ekonomi Universitas Indonesia(1).

Dendawijaya, Lukman. 2000. Manajemen Lembaga Keuangan. Jakarta : Ghali Indonesia.

Dendawijaya, Lukman. 2005. Manajemen Perbankan. Jakarta: Ghalia Indonesia. 
Eric, Helfert. 1997.Analisis Laporan Keuangan. Jakarta : Erlangga.

Ghozali, Imam. 2007. Manajemen Risiko Perbankan.Semarang : BPUNDIP.

Ghozali, Imam. 2009. Aplikasi Analisis Multivariate dengan Program SPSS.Semarang : BPUNDIP.

Harahap, Sofyan Syafri. 2004. Laporan Keuangan. Jakarta: Bumi Aksara.

Haryati, Risma. 2011. The Influence Of Working Capital and Liquidity on Profitability. Jakarta : Ghali Indonesia

IAI. 2010. Standar Akuntansi Keuangan : Jakarta. Salemba Empat.
Kasmir. 2002. Manajemen Perbankan. Edisi Pertama, Cetakan Ketiga. Jakarta: PT RajaGrafindo Persada.

Kasmir. 2003. Bank dan Lembaga Keuangan Lainnya. Jakarta: PT RajaGrafindo Persada.

Latumaerissa, Julius. 1999. Bisnis Manajemen \& Keuangan Perbankan. Jakarta : BumiAksara.

Malayu S.P, Hasibuan. 2002. Manajemen Sumber Daya Manusia. Jakarta: PT Gunung Agung.

Suwarjono. 2002. Akuntansi Pengantar, Proses Penciptaan Data, Pendekatan Sistem. Edisi Ketiga. Yogyakarta : BPFE.Artikel Ilmiah Mahasiswa 2014. 